\title{
CREDIT AND PRICE POLICIES IN
}

PHILIPPINE AGRICULTURE

\author{
Cristina C. David
}

STAFF PAPER SERIES NO, $82-2$

PHILIPPINE INSTITUTE FOR DEVELOPMENT STUDIES

MAY 1982 


\section{CREDIT AND PRICE POLICIES IN \\ PHILIPPINE AGRICULTURE}

\section{Cristina C. David*}

Government economic policies typically undervalue prices of agricultural products in low income countries (Bale and Lutz). The primary reason for this has been to keep prices of food and materials low to promote industrialization. Input price subsidies, public expenditures on irrigation, investments in research and extension, and concessionary credit policies are frequently used to offset adverse effects of price policies on production incentives in agriculture.

The credit policies and programs have stressed the expansion of the volume of agricultural loans from institutional sources at low interest rates, and have often been accompanied by supervision and input price subsidies. The underlying premise is that informal sources of funds carry high interest rates that hinder expansion of agricultural output. Officials who favor these credit policies have shown little concern for the negative effects of such policies on the ability of rural financial markets to perform efficiently. They have also ignored

*Research Fellow, Philippine Institute for Development Studies, on leave trom the latroseity of the Puilippinos et Lo Baños.

The author wishes to acknowledge support for this study from the Rural Financial Market Project of the Ohio State University, the Philippine Institute for Development Studies (PIDS), and the Philippine Council for Agricultural Resources and Research (PCARR). The analyses of price policies draw from the results of a research project entitled "The Impact of Economic Policies on Philippine Agricultural Deoelopment" funded by PIDS and PCARR. Dale Adams, Douglas Graham, John Power and James Roumasset have provided valuable comments. 
the fact that these policies usually result in more inequitable loan distribution. (Conzales-Vega)

The performance of credit programs has usually been measured in terms of theix impact on agricultural production, investment, and adoption of new technology. A recent evaluation of existing credit research, however, emphasized the serious methodological problems involved (David and Meyer). It was concluded that most micro credit impact studies are descriptive, and are more useful in generating hypotheses than in rigorously measuring loan impact. Only a few studies use econometric and mathematical programming techniques and they generally suffer from conceptual problems arising from the interdependence of production and consumption decision of farm-households, the fungibility of credit, and non-price credit rationing by lenders.

Aggregate credit impact studies also have similar methodological problems, but empirical results are more consistent in showing that little impact on production, investment, and proportion of loans granted to agriculture can be attributed to credit programs and policies (Herdt and Gonzales). These results should not be surprising because technology and relative prices across coumodities and between inputs and outputs are much more important determinants of relative profitability and, hence, direction of resource flows.

The purpose of this paper is to analyze how credit policies in the Philippines are related to economic incentives in agriculture and to analyze the entent to which cheap credit is an effectrve way to 
offset various taxes on agriculture. The first section describes the policies affecting growth of the formal agricultural credit system. The second section presents estimates of the effects of government policies on the relative prices of agricultural products. The third section argues that low interest rates do not alter the incentive structure facing agriculture nor resolve equity problens caused by price policies.

\section{Agricultural Credit Policies}

Credit has been a major agricultural development instrument in the Philippines. In the early fifties, the Rural Bank Law was passed to promote rural private banks and the Agricultural Credit and Cooperative Farmer's Association (ACCFA) was also established to promote cooperative financial institutions catering especially to the rural sector. There are currently more than a thousand rural banks operating in about 60 per cent of municipalities. They have become the principal distributors of government-eponsored supervised credit. The ACCFA was supposed to develop farm cooperatives, providing production and marketing credit, but because of serious default problems, it was reorganized and renamed the Agricultural Credit Administration (ACA). It now administers a small supervised credit program for land reform beneficiaries.

The government's objective of increasing the credit flow to agriculture has been hampered by low interest rates policies. Ip until the 1981 interest rate reform, interest rates and other financial charges have been regulated by the Monetary Board to conform with the 16 per 
cent ceiling stipulated by the Usury Law of 1916 . During the past decade, allowable interest rates of formal agricultural credit ranged from 12 to 16 percent and additional loan charges from 2 to 3 percent depending on the security and other terms of the loans. Supervised credit bears a lower interest rate of 10 percent with additional charges not exceeding 3 percent. For rural savings deposits, the interest rates were about 6 percent but higher for time deposits.

Since the late sixties, official interest rates on agricultural credit have been lower than the scarcity price of loanable funds, with negative consequence on the rate of savings, investments in agriculture, and factor intensities (International Labor Organization). Because of rapid inflation (around 20 percent during the $1970^{\prime} \mathrm{s}$ ), interest rates were negative in real terms. This price structure rewarded borrowers and penalized savers. This also created excess loan demand that limited the flow of loans to agriculture, especially to small farmers, where costs of transactions and risks for lenders were inherently higher.

To increase agricultural credit, the government required a certain proportion of lenders' portfolios of loans go to credit for agriculture and initiated a number of supervised agricultural credit programs. In 1974, the Monetary Board directed all lending institutions to allocate 25 percent of their loanable funds to agriculture and at least 10 per cent of total to agrarian reform beneficiaries. Private commercial banks, however, have strongly reoisted this rule and have simply purchased certificates of indebtedness and other government securities 
issued by the Central Bank to comply with the regulation because of the high cost of directly lending to farmers.

Table 1 lists the various special agricultural credit programs (SCPs) and their corresponding total loans granted during the period 1973-1980. Most of these programs linked low interest, non-collateral loans with extension. Between 1973 and 1975, these were also tied to a fertilizer price subsidy. Financial institutions were provided preferential rediscount rates, loan guarantees, and assistance in loan administration under these programs. These were financed, in part, by foreign loans.

A major rice production promotion program, Masagana 99, accounted for almost 80 percent of total loans granted by SCPs. Since the initial objective of Masagana 99 was to recover from serious crop losses in 1973, priority was given to irrigated areas where the potential for rapid expansion of rice production in the short-run was greatest. Programs after Masagana 99, although much smaller in scale, attempted to extend supervised credit to non-rice, rainfed areas.

Problems associated with these programs and policies are now welldocumented (David). Over the past two decades, growth in agricultural loans came mainly from the Central Bank rediscount window rather than from additional equity capital or savings deposits. This is evidenced by the increase in the share of borrowings. from the Central Bank in total resources of rural banks from 8 percent in 1961 to 54 percent in 1975. Low repayment rates, which have plagued almost all supervised 
Table 1. Supervised Agricultural Credit Programs in the Philippines from 1973 to 1980.

\begin{tabular}{|c|c|c|c|}
\hline & Program & Commodity & $\begin{array}{c}\text { Loans Granted } \\
\text { ( } \not \mid \text { million) }\end{array}$ \\
\hline 1. & Masagana 99 & Rice & 4,554 \\
\hline 2. & $\begin{array}{l}\text { Masaganang Maisan and } \\
\text { Masagana } 77\end{array}$ & Corn & 521 \\
\hline 3. & Gulayan sa Kalusugan & Vegetables & 22 \\
\hline 4. & Cotton Financing Progress & Cotton & 71 \\
\hline 5. & $\begin{array}{l}\text { Integrated Agricultural } \\
\text { Financigg for Virginia } \\
\text { Tobacco }\end{array}$ & Tobacco & 34 \\
\hline 6. & $\begin{array}{l}\text { Rice-Tobacco Supervised } \\
\text { Credit Program }\end{array}$ & Tobacco & 3 \\
\hline 7. & $\begin{array}{l}\text { Philippine Tobacco Administration } \\
\text { (PTA) Farm Credit Assist. Program }\end{array}$ & Tobacco & 3 \\
\hline 8. & PTA Facility Loans & Tobacco & 1 \\
\hline 9. & Bakahang Barangay & Cattle & 256 \\
\hline 10 & Biyayang Dagat & Fish & 35 \\
\hline & Tota1 & & $\not 5,500$ \\
\hline
\end{tabular}

al As of December 31, 1980.

b/As of 1979 .

Source: Unpublished files. Technical Board of Agricultural Credit, Central Bank of the Philippines. 
credit programs, threatened the viability of rural credit institutions, and further damaged credit discipline among borrowers. The impact of these programs on production at the farm level as well as at an aggregate level has remained unclear. While the Masagana 99 helped the rapid recovery of Philippine rice production from the global food grain crisis in 1973, the growth trend in rice production and adoption of the new rice technology since the late sixties cannot be attributed to Masagana 99 (Herdt and Gonzales).

Despite these government interventions, Table 2 indicates that the real and relative levels of agricultural production loans (APL) granted have declined since the late 1960's. APL grew in real terms but most of this growth took place in the $1960^{\prime} \mathrm{s}$. The level of APL in 1979 was still far below that in 1969. APL as a percent of net value added in agriculture and total loans granted declined from 22 percent and 20 percent in 1955-1969 to 19 percent and 11 percent, respactively, in the $1970^{\prime} \mathrm{s}$.

These trends are perhapg not surprising since technology and relative prices across sectors, commodities, and between inputs and outputs are more important determinants of relative profitability and hence direction of resource allocation. Larson and Vogel and others have already argued that the use of credit policies to compensate for the effects of policies that turn terms of trade against food and agricultural exports will have limited effects. It is too often overlooked that preferential interest rates do not affect relative 
Table 2. Selected Indicators of Trends in Loans Granted for Agricultural Production by Bank and Non-Bank

Financia1 Institutions, 1951-1979.

\begin{tabular}{|c|c|c|c|}
\hline Year & $\begin{array}{c}\text { Value of } \\
\text { Agricultural Loansa/ } \\
\text { ( } \mathbf{p} \text { Million in } \\
1979 \text { Prices) } \\
\end{array}$ & $\begin{array}{l}\text { Agricultural Loans } \\
\text { Agricultural } \\
\text { Value Added }\end{array}$ & 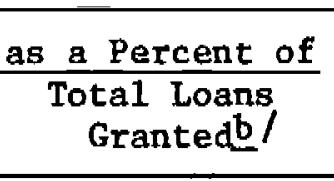 \\
\hline $\begin{array}{l}1951 \\
1955 \\
1960 \\
1961 \\
1962 \\
1963 \\
1964 \\
1965 \\
1966 \\
1967 \\
1968 \\
1969 \\
1970 \\
1971 \\
1972 \\
1973 \\
1974 \\
1975 \\
1976 \\
1977 \\
1978 \\
1979\end{array}$ & $\begin{array}{r}376 \\
534 \\
2,757 \\
3,636 \\
4,022 \\
4,461 \\
4,503 \\
4,420 \\
4,582 \\
5,556 \\
5,665 \\
5,794 \\
4,557 \\
3,943 \\
3,424 \\
2,590 \\
1,725 \\
1,718 \\
982 \\
1,096 \\
2,534 \\
3,378\end{array}$ & $\begin{array}{l}13 \\
17 \\
14 \\
19 \\
21 \\
24 \\
25 \\
23 \\
24 \\
27 \\
25 \\
22 \\
22 \\
21 \\
20 \\
19 \\
22 \\
21 \\
13 \\
06 \\
13 \\
19\end{array}$ & $\begin{array}{l}40 \\
24 \\
20 \\
22 \\
20 \\
20 \\
19 \\
19 \\
19 \\
20 \\
16 \\
16 \\
15 \\
13 \\
12 \\
10 \\
12 \\
09 \\
- \\
08 \\
- \\
-\end{array}$ \\
\hline
\end{tabular}

a/ Refers to loans granted for agricultural production only.

b/For later years, data on total loans granted have not been reported.

Sources: Unpublished reports by the Technical Board of Agricultural Credit, Centra1 Bank of the Philippines, and the National Economic and Development Authority. 
profitability. And because credit is fungible, additional liquidity supplied by credit will be allocated to the most profitable enterprise or to consumption, whichever provides the greatest utility.

\section{Price Intervention Policies}

The effects of government policies on economic incentives in agriculture have not received adequate attention in the Philippines. The fact that small farmers are rational and price-responsive has been amply demonstrated by researchers elsewhere. Price relationships among crops, between agriculture and non-agriculture, between product and input prices have been shown to have inportant consequences on resource allocation as well as on income distribution. In the Philippines, these price relations have been influenced by interventions intended to achieve severa1, of ten conflicting objectives: food self-sufficiency, low food prices, stable prices, higher farm income, more government revenues, and increased processing of agricultural products. In addition, price controls, export taxes, trade quotas, import tariffs, nationalization of marketing, and the general overvaluation of domestic currency have been important policies affecting relative prices especially during the past decade. Domestic prices have also been influenced by policies of other countries such as the US sugar quota policy prior to the 1970's and the US PL 480 program.

The impact of economic policies on agricultural incentives can te measured by the nominal protection rates (NPR) and implicit tariffs (IT). Both NPR's and IT's measure the percentage difference between domestic 
price and border price of products and inputs, respectively. $\stackrel{l}{/}$ Border prices (usually defined as CIF import price for importables or FOB export prices for exportables)converted at official exchange rates are used as bases of comparison because they represent opportunity costs of commodities that enter trade. When border price is converted at the official exchange rates, as in NPR or IT, the difference between domestic and border price is attributed to government price interventions such as trade, fiscal, and price policies. On the other hand, by converting border price by the shadow exchange rate, a measure of net nominal protection rate, which takes into account all government policies, including the general overvaluation of the exchange rate defended by the protection systen, is obtained.

Table 3 presents average NPR's for the Philippines by major commodity groups for two time periods to highlight the impact of increasing government regulation of the agricultural sector. $2 /$ while government intervention in the later period was part of the overall attempts to balance economic growth, many policies were instituted to cushion the impact on consumer prices of the floating of exchange rates in 1970

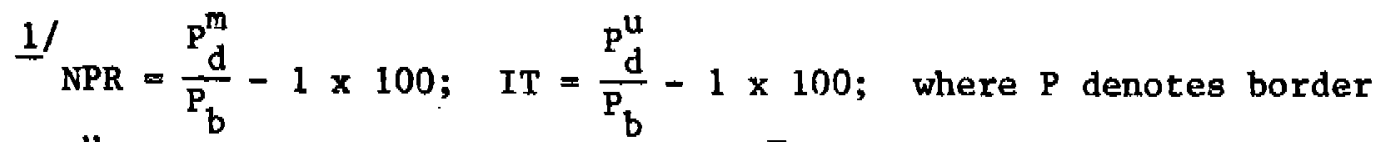
price, $\mathrm{P}_{\mathrm{d}}^{\mathrm{u}}=$ price paid by the user, and $\mathrm{P}_{\mathrm{d}}^{\mathrm{ml}}=$ price received by domestic producers and importers. Prices are defined at a comparable point in the marketing chain to insure that differences between domestic and border prices are due to government interventions rather than to real costs.

$2 /$ Annual differences in nowinal protection rates were not shown because they would, in general, be related to price fluctuations rather than to policy changes. 
Table 3. Nominal Protection Rates in Philippine Agriculture, 1955-1980.

\begin{tabular}{cccc}
$\begin{array}{c}\text { Proportion } \\
\text { of Value } \\
\text { Added }\end{array}$ & $\begin{array}{c}\text { Nominal } \\
\text { Protection } \\
\text { Rate }(\%)\end{array}$ & $\begin{array}{c}\text { Proportion } \\
\text { of Value } \\
\text { Added }\end{array}$ & $\begin{array}{c}\text { Nominal } \\
\text { Protection } \\
\text { Rate }(\%)\end{array}$ \\
\hline
\end{tabular}

Food Crops

$\begin{array}{llllr}\text { Rice } & .27 & 4 & .25 & -7 \\ \text { Corn } & .09 & 2 & .08 & 1 \\ \text { Other Crops } & .13 & 0 & .18 & 0\end{array}$

Export Crops

$\begin{array}{lrrrr}\text { Sugar } & .09 & 60 & .09 & -23 \\ \text { Copra } & .09 & -8 & .08 & -22 \\ \text { Other Exports } & .09 & 0 & .12 & -4\end{array}$

Livestock and Poultry

$\begin{array}{llllr}\text { Livestock } & .17 & 28 & .13 & 4 \\ \text { Poultry } & .07 & 77 & .07 & 48\end{array}$

$\begin{array}{lllll}\text { Average (Total) } & (1.00) & 15 & (1.00) & -2\end{array}$


and the oil and food grain crises in 1973.

\section{Import Competing Food Crops}

Among the domestically marketed food crops, the food staples, rice and corn, have historically been the objects of direct frice interventions. Prices of other food crops such as vegetables, fruits, nuts, roots, and tubers were less controlled except potentially by the tariff structure. $\underline{3}$ / Domestic prices of rice and corn have been generally close to border prices. In the $1970^{\prime} \mathrm{s}$, domestic rice price was below the border price by 7 percent. In part, this was due to the price interventions in 1973-1975 when world prices of rice and fertilizer rose fourfold because of the oil crisis and world-wide grain shortages.

The National Food Authority (NFA) is responsible for regulating food grain prices to achieve low prices for consumers and adequate price incentives for producers. It buys grains in the domestic market to defend a farm floor price, but the amount of imports or exports which are under government monopoly is the main determinant of grain prices. Previous studies had noted that the provision of stable and low rice prices for urban consumers tended to daminate the objective of supporting farm price to raise incomes of small farmers (Mangahas). This was

3/ Tariff protection is redundant for exportable crops and does not apply to food grains where only the goverament can import or export. It should also be noted that tariffs are expected to be effective in raising domestic price over border prices only in potentially import competing products. Since most of the agricultural commodities are either subjected to quantitative trade restrictions or are not significantly traded, price comparisons have been used to measure NPR instead of legal tariff rates. 
achieved through imports during years of production shortfalls. After 1975, the domestic rice prices became internationally competitive, Some commercial rice exports have occurred since 1978 as a result of the new rice technology and irrigation expansion. Price policy for corn, an important upland crop and the staple food for about 20 percent of the population, also has the same bias. Moreover, the policy of keeping the price of meat low for urban consumers is another reason for maintaining a relatively low price of corn.

\section{Export Crops}

Growing regulation of agriculture in the 1970 's has been significant in the export sector. Prior to 1970 , the government rarely intervened in the production and trade of export crops except indirectly through the overvaluation of exchange rates and other regulations relating to foreign exchange. However, in the case of sugar, export quotas that limited exports to 60 percent of production were instituted in 1962 to protect domestic consumers from the increased access of Philippine producers to the highly protected U.S. sugar market. Despite this, the incentive effect of the U.S. sugar quota policy that provided an export price much higher than world prices from 1955 to 1969 resulted in a high nominal protection rate of 60 percent on domestic sugar production.

During the $1970^{\circ} \mathrm{s}$, government policies generally reduced domestic prices of export crops below those that would have prevailed under the previous policy regime. Since the floating of the exchange rate in 1970, many agricultural crop exports have been penalized by export taxes 
ranging from 4 to 6 percent. The rate of 6 percent is levied on traditional exports of copra and centrifugal sugar to promote higher degrees of processing of agricultural exports. Other export crops subject to a 4 percent export tax are processed coconut products, molasses, abaca, bananas, and tobacco. Between 1973 and 1975, additional export premium duties were temporarily levied to siphon off part of the gains from higher world prises. These export taxes were initially imposed as stabilization measures, but they have been continued as a tax on agriculture.

In the case of sugar and copra, the penalty or implicit tax on producers rose to more than 20 percent due to new regulations in these industries. Since 1970, sugar trading has effectively been nationalized, first under the Philippine Exchange, Inc., and currently under the National Sugar Trading Corp., which has become the sole wholesale buyer and seller of sugar in both domestic and international markets. Producers are paid a composite price that theoretically is a weighted average of export price, domestic wholesale price, and domestic reserve price. However, as in the quota system, this arrangement has served to lower the domestic price significantly below export prices thereby transferring incone from domestic producers to domestic consumers.

Two taxes called the Coconut Consumer Stabilization Fund (CCSF) and the Coconut Investment Fund (Cocofund) have been imposed on the coconut industry since 1973. The tax rates have changed over time, typically rising and falling with the world price of copra. In some 
years, the CCSF levy in ad valorem terms represented a tax of about 20 percent of border price. Although the tax is collected at the miller's level, the incidence of the tax is clearly at the farm level.

About 20 percent of the revenues from the tax supports the direct subsidy on domestic consumption of coconut oil products. The remainder is supposed to finance development programs in the coconut industry such as replanting, vertical integration, and scholarships. Research, to date, shows that only a small segment of the coconut industry actually receives the benefits from these programs (David, 1977). On the other hand, the gains from the replanting program are uncertain. It is not known how well hybrid seeds will perform under diverse Philippine conditions. Furthermore, small coconut farmers with no alternative source of income have been hesitant to face the prospect of waiting for three years to harvest a first crop. At least for the short run, the CCSF and Cocofund levies may be considered a tax on the industry .

\section{$\underline{\text { Livestock and Poultry }}$}

The incentive structure for livestock appears to offer lower rewards than for poultry, but both are more favored than the crop sector. However, the general trend of declining incentives over time because of government policy also seems to have occurred. Domestic prices of livestock, specifically pork, and poultry were 28 percent and 77 percent higher than their corresponding border prices prior to the $1970^{\prime}$ s and slightly higher than those predicted by their tariff 
rates. 4 In the $1970^{\prime} \mathrm{s}$, percentage price difference declined to levels somewhat lower than the legal tariff rates of 10 percent for livestock and 70 percent for poultry. This may be due to price controls imposed on those products which were accompanied also by price controls on mixed feeds and feedgrains, higher imports of corn, and other feedgrains to provide a reasonable margin for producers during this period.

Protection of Agriculture and Manufacturing

The direction and rate of resource flows between agriculture and non-agriculture are not only influenced by the nominal rate of protection on product prices; they also depend on the effects of policies on agricultural input prices and on the nature of incentives in the nonagricultural sector. The effective protection rate (EPR) measures the percentage difference between value added at domestic prices and value added at border prices. It takes the impact of price interventions on inputs into account. Since estimates of EPR for agriculture are not available, Table 4 compares the nominal protection rate in agriculture to the implicit tariffs paid by farmers for agricultural inputs and to EPR for manufacturing as estimated by Tan. $\underline{5}$

$4 /$ Since international trade in livestock and poultry has been minimal and confined mainly to imports of breeding aninals, special cuts of meat for restantante or of fats for the meat processing industry and their border prices were represented by the average CIF import unit values in Hongkong.

5/NPR's in agriculture are not expected to be substantially different from their EPR's because the proportion of intermediate inputs to value added remains relatively small in Philippine agriculture. Moreover, one can expect EPR's to be lower than NPR's because of higher protection on agricultural inputs. 
As can be noted, government policies have created an incentive structure that is significantly hiased against agriculture. While value added in manufacturing has been artificially raised by 44 percent, price intervention policies undervalued agricultural production during the last decade through lower product prices and higher input prices.

Because low food prices tend to dominate the objective of agricultural product price policy, it was expected that government interventions in the agricultural input markets will try to offset this. However, it is only in the case of gravity irrigation, and formal rural credit, as will be discussed later, where there appears to be soee government subsidy to producers. Implicit tariffs for agricultural chenicals, agricultural machineries, and feed mixes ranging from 24 to 46 percent reduce the effective protection in agriculture as a result of the structure of legal tariffs and indirect sales tax. Despite price controls and direct subsidies on fertilizer, there is still a positive implicit tariff for fertilizer. It appears that the protection of domestic manufacturing of these agricultural inputs, which is also indicated by the level of implicit tariffs or IT but is actually significantly higher for fertilizer because of direct subsidies), has been an important consideration of policy.

The overall magnitude of the bias against agriculture is reflected by the measure of net protection rates that includes the impact of the overvaluation of the exchange rate due to the protection system. Although the exchange rate has been allowed to float since 1970, the structure of 
Table 4. Comparison of Protection Rates in Agriculture and Manufacturing Sector, 1970's.

Agriculture (Nominal Protection Rates)

(Net Nominal Protection Rate)

Agricultural Inputs (Implicit Tariffs)

Fertilizer ${ }^{a /}$

Agricultural Chemicals $\underline{b}$ /

Hand Tractors $b /$

Four-wheel Tractors $\mathrm{b} /$

Irrigation Pump

Irrigation Gravity (NIA system) c/

Mixed Feeds - l

Manufacturing (Effective Protection Rate)

(Net Effective Protection Rate)
$-2$

$-37$

10

28

46

24

46

$-55$

44

9

a/ Based on price comparison of urea, ammonium sulphate, nixed fertilizer and phosphates from 1973-1980.

b/Based on legal tariff rate and sales tax.

c/Based on comparison of NIA irrigation fee and estimates of annualized cost of irrigation system by Moya, P.F., L. Sma11, and S. Bhuiyan, "Cost of Different Types of Irrigation System in Central Luzon," Department Paper No. 80-10, Dept. of Agricultural Economics, IRRI, June 1980.

d/ Based on estimates by Tan, N. "The Structure of Protection and Resource Flows in the Philippines," in Bautista, R., and J. Power, Industrial Promotion Policies in the Philippines, Philippine Institute for Development Studies, 1979. 
tariffs and other trade restrictions has reduced demand for imports and thus increased the value of domestic currency. For the mid-1970's, Medalla estimated that the tariff and tax system resulted in a 32 per cent overvaluation of the pesos relative to a balanced free trade situation. $6 /$ If this is taken into consideration, penalties to agriculture net of the disincentive effect of an overvalued currency would be even more severe ( -37 percent) while manufacturing still receives a 9 percent net effective protection rate. As a consequence of this general pricing policy, agricultural production is less than what it should be, and for certain comodities such as coconut products and sugar, the level of domestic consumption may be somershat higher than would be expected with no price intervention. The fact that agriculture survives and indeed grows suggests an inherent comparative advantage.

Impact of Credit Policies

To compare the quantitative impact of credit policies to price policies, the effective subsidy rate (ESR) which expresses the amount of interest rate subsidy as a percent of net value added in agriculture at border prices has been estimated. Subsidy is defined in terms of the difference in the cost of borrowing between agricultural and nonagricultural loans multiplied by the value of agricultural loans granted. Another method is to estimate the amount of subsidy accruing to the

$6 /$ The situation since the mid-1970's has been one of chronic and growing deficits in current accounts, financed by heavy foreign borrowing. This indicates an even higher percentage of peso overvaluation than that protected by the tariff and tax system alone. 
sector due to the difference between the nominal interest rate and the rate of inflation.

Differences in interest rates between agricultural and nonagricultural loans from formal financial institutions are sma11, at most, 2 percent. Moreover, interest represents only part of the costs of borrowing. Typically, non-agricultural loans entail less transaction cost than agricultural loans for borrowers.

Assuming that interest rate policy has meant a cost of borrowing differential of 6 percent in favor of agriculture, the effective subsidy rate amounts to only 1 percent. Even if interest rate differential is increased two or three times in magnitude, it is clear that the interest rate subsidy will not alter significantly the unfavorable incentive structure in agriculture vis-a-vis non-agriculture created by price policies. On the other hand, low interest rate policy seriously impairs the ability of rural financial markets to efficiently perform the financial intermediation process. It does not provide incentives for mobilizing financial savings and it induces an allocation of credit that is based on size of collateral and wealth rather than productivity of credit use.

The impact of the low interest rate policy on income distribution tends to be regressive. The implicit subsidy is shouldered by the lower income population, i.e., holders of currency, bank deposits, and tax payers through inflation, low interest rates on savings, and direct government outlay. 
Only about 10 percent of the total implicit interest rate subsidy is received by agriculture. Within agriculture, credit allocation is also not consistent with employment and equity objectives. Low cost credit for agricultural machinery shifts the incentive system against use of labor without significant impact on yield. Less than 15 percent of the value of loans in the World Bank Credit Mechanization Program in the Philippines was used for power tillers of small farmers. Four-wheel tractors and other larger farm equipment were purchased with the bulk of the loans by sugar farmers with 50 hectares or more who constituted less than 10 percent of total number of farmers.

In supervised credit programs, only farm operators are usually entitled to institutional credit despite the significant number of landless households in the rural areas. Rice has been the emphasis but rice farmers are actually better off than average farmers in corn, coconut, tobacco, and other crops. Within the rice sector, priority was given to irrigated areas close to primary markets, i.e., relatively progressive locations with the greatest potential for rapid increases in production in the short-run. The procedure of setting loan limits on a per hectare basis weans a higher credit ceiling for larger farms. Perhaps an even more important dimension of inequity in distribution of the implicit subsidies involved in these programs was reported by Esguerra in a recent analysis of Masagana 99 . The study estinated that two-thirds of the implicit subsidies have been received by participating financial institutions as incentives to lend to small farmers and only one-third by the farmer borrowers mainly from non-repayment of loans. 
Furthermore, the distribution of the subsidies accruing to farmer borrowers has been biased in favor of larger farmers. The subsidy to farmers can be increased through higher default rates but this would simply transform supervised credit into a costly vehicle for effecting income transfers.

The comon belief that extension would be more effective if tied with low cost credit and vice versa is not clearly borne out by empirical evidence. In the case of rice, the modern varieties introduced in 1967 were already adopted by 67 percent of irrigated farms and by 45 percent of rainfed farms prior to the Masagana 99 Program. The fact that the rate of adoption increased to 85 percent and 71 percent, respectively, in 1977 cannot belattributed to the program but rather should be viewed as a continuation of the long-run adoption process of the new technology extended since the late 1960's. In the case of corn, there has been little dissemination of new varieties developed in the early $1970^{\prime} \mathrm{s}$ despite the Maisan 77 and Masaganang Maisan programs because the nev technology apperently did not offer higher profitability. Extension and development of financial markets are indeed important components of rural development, but the strategy of linking the two has dissipated the efforts of scarce competent technicians in loan adeiniatration without significantly raising repayment rates in supervised credit prograns .

\section{Concluding Remarks}

In summary, interest rate subsidies have not significantly altered 
the unfavorable economic incentives in agriculture caused by government policies. It is not surprising, therefore, that loanable funds to agriculture in real terms have declined despite government instituted credit quotas and special credit programs. Even higher rates of interest rate subsidies will be ineffective in offsetting penalties due to pricing policies because of the fungibility of credit. Additional liquidity will be allocated to activities where marginal profits or utility are highest. Relative prices 38 well as yialds are the major factors determining rates of return to most enterprises. Cheap credit will not make an unprofitable activity profitable:

It is also clear that credit subsidies through low interest rates worsen income distribution because only a few, typically progressive farmers, receive the cheap credit. When interest rates are not allowed to reflect cost of financial intermediation, wealth and political power replace profitability as the basis of allocating credit. On the other hand, more positive agricultural prices vould benefit more low income farmers.

The choice of credit policies to compensate agriculture for other adverse policies is due to administrative ease, availability of external grants and loans, and to other short-run considerations. While easy to do, this approach fails to achieve either equity or efficiency objectives. Cheap credit policies also retard the development of viable formal financial institutions in rural areas. The objectives of food selfsufficiency, increasing exports, and improving income distribution 
requires long run solutions. This includes correcting price distortions in real and financial markets and making investments in marketing infrastructure, irrigation, research, and extension. Cheap credit will not overcome production disincentives caused by low prices and/or low yielda. 


\section{REFERENCES}

Bale, M. and E. Lutz, "Price Distortions in Agriculture and Their Effects: An International Comparison", Wor1d Bank Staff Working Paper No. 359, October 1979.

David, C, and R. Meyer, "Measuring the Farm Level Impact of Agricultural Loans in Low Income Countries: A Review Article", in Borrowers and Lenders, OEDB, London, 1980.

David, C., "Structure and Performance of Rural Financial Markets in the Philippines", ESO No. 598, Department of Agricultural Economics and Rural Sociology, The Ohio State University, May 1979.

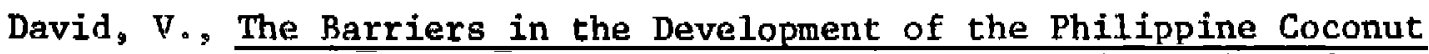
Industry, Unpublished MBA thesis, Ateneo de Manila University, 1977.

Esguerra, E., The Redistributive Potential of the Masagana 99 Credit Subsidy, Unpublished MA thesis, School of Economics, University of the Philippines, August 1981.

Gonzales, Vega, Claudio, "Interest Rate Restrictions and Income Distribution", American Journal of Agricultural Economics, Vol. LIX, No. 5, December 1977.

Herdt, R. and L. A. Gonzales, "A Reaction to the Study on the Benefits and Costs of Masagana 99 Program", Paper presented at the Fifth National Agricultural Credit Workshop, Zamboanga, Philippines, March 1981.

International Labour Organization. Sharing in Development: A Progranme of Employment Equity and Growth for the Philippines, Geneva, International Labour office, 1974.

Larson, D. W. and R. C. Vogel, "Interaction of Price and Credit Policies in Costa Rica Agriculture", ESo No. 813, Department of Agricultural Economics and Rural Sociology, The Ohio State University, November 1980.

Mangahas, M., "Philippine Rice Policy Reconsidered in Terms of Urban Bias," IEDR Discussion Paper 72-8, School of Economics, 1972.

Medalla, E. and J. Power, "Estimating Implicit Tariffs and Nominal Rates of Protection", in Bautista, $R_{\text {o }}$ and Power $J$. Industrial Promotion Policies in the Philippines, Philippine Institute for Development Studies, 1979.

Moya, P. and Others, "Cost of Different Types of Irrigation System in Central Luzon", Paper No. 80-10, Department of Agricultural Economics, International Rice Research Institute, Los Baños, Philippines, June 1980.

Tan, N., "The Structure of Protection and Resource Flows in the Philippines", in Bautista, R. and Power, Jo Industrial Promotion Policies in the Philippines, Philippine Institute for Development Studies, 1979. 


\section{(c) (1) (9)}

This work is licensed under a

Creative Commons

Attribution - NonCommercial - NoDerivs 3.0 License.

To view a copy of the license please see: http://creativecommons.org/licenses/by-nc-nd/3.0/ 